\title{
Why permafrost rocks become unstable: a rock-ice- mechanical model in time and space
}

\begin{tabular}{|r|l|}
\hline Journal: & Earth Surface Processes and Landforms \\
\hline Manuscript ID: & ESP-12-0025.R2 \\
\hline Wiley - Manuscript type: & Special Issue Paper \\
\hline Complete List of Authors: & $\begin{array}{l}\text { Krautblatter, Michael; Technical University Munich, Engineering Geology } \\
\text { Funk, Daniel; University of Bonn, Department of Geography } \\
\text { Günzel, Friedrike; University of Brighton, School of Environment and } \\
\text { Technology }\end{array}$ \\
\hline Keywords: & $\begin{array}{l}\text { mountain geomorphology, paraglacial geomorphology, rock slope stability, } \\
\text { permafrost, rock-ice mechanics }\end{array}$ \\
\hline & \\
\hline
\end{tabular}


Keywords: mountain geomorphology, paraglacial geomorphology, rock slope München, Munich, Germany

${ }^{b}$ Department of Geography, University of Bonn, Bonn, Germany

${ }^{c}$ University of Brighton, Brighton, UK

* Arcisstrasse 21, 80333 München, Germany, Phone +49 8928925866 Fax +49 89289 25852; mail:

m.krautblatter@tum.de

stability, permafrost, rock-ice mechanics,

\section{Abstract:}

In this paper, we develop a mechanical model that relates the destabilisation of thawing permafrost rock slopes to temperature-related effects on both, rock- and icemechanics; and laboratory testing of key assumptions is performed. Degrading permafrost is considered to be an important factor for rock-slope failures in alpine and arctic environments, but the mechanics are poorly understood. The destabilisation is commonly attributed to changes in ice-mechanical properties while bedrock friction and fracture propagation have not been considered yet. However, fracture toughness, compressive and tensile strength decrease by up to $50 \%$ and more when intact water-saturated rock thaws. Based on literature and experiments, we develop a modified Mohr-Coulomb failure criterion for ice-filled rock fractures that incorporates fracturing of rock bridges, friction of rough fracture surfaces, ductile creep of ice and detachment mechanisms along rock-ice interfaces. Novel laboratory 
1 setups were developed to assess the temperature dependency of the friction of ice-

2 free rock-rock interfaces and the shear detachment of rock-ice interfaces. In 3 degrading permafrost, rock-mechanical properties may control early stages of 4 destabilisation and become more important for higher normal stress, i.e. higher 5 magnitudes of rock slope failure. Ice-mechanical properties outbalance the 6 importance of rock-mechanical components after the deformation accelerates and 7 are more relevant for smaller magnitudes. The model explains why all magnitudes of 8 rock slope failures can be prepared and triggered by permafrost degradation and is 9 capable of conditioning long paraglacial response times. Here, we present a synoptic 10 rock- and ice-mechanical model that explains the mechanical destabilisation 11 processes operating in warming permafrost rocks.

\section{Introduction}

14 Degrading permafrost in rock walls is considered to be an increasing hazard in alpine 15 environments due to both, rockfall activity and slow rock deformation endangering 16 infrastructure and potentially causing casualties (Brommer et al., 2009). The

17 increasing importance of hydro-electric power generation and storage in high18 topography settings and the trend towards high-alpine winter and adventure tourism 19 increases the vulnerability to permafrost rock slope failure and requires improved 20 assessment and monitoring strategies for permafrost rock walls (Haeberli et al., 21 1997; Messerli, 2006). Enhanced activity of rock slope failure in permafrost-affected 22 rock slopes has been investigated at several sites in the last years. Rock-ice 23 avalanches of bergsturz size (release volumes $>1 \mathrm{Mm}^{3}$ ) were documented, e.g. at 24 Mt. Steller, Alaska $\left(5( \pm 1)^{*} 10^{7} \mathrm{~m}^{3}\right)$ in 2005 , at Dzhimarai-Khokh, Russian Caucasus $25\left(4^{*} 10^{6} \mathrm{~m}^{3}\right)$ in 2002 , at Mt. Steele, Yukon $\left(5.5^{*}( \pm 2.5)^{*} 10^{7} \mathrm{~m}^{3}\right)$ in 2007 , at Harold Price, 
1 British Columbia $\left(1.6^{*} 10^{6} \mathrm{~m}^{3}\right)$ in 2002 and at the Brenva $\left(2^{*} 10^{6} \mathrm{~m}^{3}\right)$ and the Punta

2 Thurwieser $\left(2^{*} 10^{6} \mathrm{~m}^{3}\right)$ in the Italian Alps in 1997 and 2004 (Bottino et al., 2002;

3 Haeberli et al., 2004; Geertsema et al., 2006; Huggel et al., 2008; Lipovsky et al.,

4 2008; Sosio et al., 2008). Recently, rock avalanches of a few million $\mathrm{m}^{3}$ detached

5 from permafrost summits such as the Bliggspitze, Kauner Valley, Austria in 2007 and

6 in December 2011 at the Pizzo Cengalo, Bergell, Switzerland in the Alps. Enhanced

7 activity of cliff falls $\left(10^{4}-10^{6} \mathrm{~m}^{3}\right)$, block falls $\left(10^{2}-10^{4} \mathrm{~m}^{3}\right)$, boulder falls $\left(10^{1}-10^{2} \mathrm{~m}^{3}\right)$ and

8 debris falls $\left(<10 \mathrm{~m}^{3}\right)$ was detected in several permafrost-affected rock faces (Fischer

9 et al., 2007; Krautblatter and Dikau, 2007; Sass et al., 2007; Rabatel et al., 2008;

10 Ravanel and Deline, 2008).

11 It has been postulated, that permafrost-distribution can significantly influence the

12 stability of permafrost rock slopes and responds quickly to climatic fluctuations

13 (Fischer and Huggel, 2008; Fischer et al., 2010). Three types of field evidence have

14 been presented in the literature: (i) the exposure of ice at rockfall backscarps

15 subsequent to failure (Dramis et al., 1995; Haeberli et al., 2004; Gruber and Haeberli,

16 2007) as well as the (ii) spatial and (iii) temporal coincidence of rock slope failure and

17 thermal disturbances in permafrost rock walls. Huggel (2009) states that detachment

18 zones of rock-ice avalanches indicate thermal disturbances caused by the interaction

19 of permafrost, glacial ice, volcanic/geothermal effects and climate change. These

20 relations were suggested for, e.g. the Kolka-Karmadon slide, Caucasus (Haeberli et

21 al., 2003); the Iliamna avalanches, Alaska (Huggel et al., 2007); the Mt. Steller

22 avalanche, Alaska (Huggel et al., 2008) and the Monte Rosa failure, Italy (Fischer et

23 al., 2006). A spatial relationship between permafrost degradation and rockfall was

24 detected by Noetzli et al. (2003) for the European Alps and by Allen et al. (2009) for

25 the Southern Alps, New Zealand. The correspondence of annual and decadal warm

26 periods with enhanced rockfall activity from permafrost cliffs has also been 
1 postulated (Gruber et al., 2004; Rabatel et al., 2008). The abductive scientific

2 reasoning of "increasing permafrost-related instability" based on the short time frame

3 of recorded rock slope failures in high mountains is still difficult. It is, thus, important

4 to develop a deductive systemic understanding based on the physical process

5 linkage between permafrost degradation and rock instability (Krautblatter et al., $62012)$.

7 Permafrost dynamics influence rock slope stability due to increasing shear stresses 8 and reducing shear resistance. Water pressure and ice segregation enhance shear 9 forces in permafrost rocks. Fischer et al. (2010) modelled the effects of enhanced 10 hydrostatic pressure due to a perched water level sealed by permafrost (Krautblatter 11 and Hauck, 2007; Krautblatter et al., 2010). Ice segregation possibly acts to prepare 12 planes of weakness by creating and extending microfractures (Murton et al., 2000; 13 Matsuoka, 2001; Murton et al., 2006). While macrogelivation (frost wedging) is 14 postulated to operate in rock discontinuities close to the surface (Matsuoka, 2001), 15 microgelivation (ice segregation) could physically operate in several meters depth, 16 where permafrost is found in Alpine environments. Upward freezing due to ice 17 segregation could cause propagating ice-filled fractures, which may provide a slip 18 plane during thawing (Matsuoka and Murton, 2008). However, the critical moisture content required for effective frost action (Prick, 1997) and the effectiveness of 20 microgelevation in hard low-permeability rocks requires further research (Hall et al., 21 2002; Whalley et al., 2004). Degradation and warming of permafrost might also 22 influence the shear resistance of rock masses. In constant strain experiments (where 23 shear velocity is kept constant), the shear strength of ice-filled fractures is a function 24 of temperature and normal stress (Davies et al., 2000; Davies et al., 2001; Davies et 25 al., 2003; Günzel, 2008). The shear strength of the fracture declines with increasing 26 temperature of the ice between $-5{ }^{\circ} \mathrm{C}$ and $0{ }^{\circ} \mathrm{C}$. Shear strength of the ice-filled 
1 fractures in the presence of warm ice $\left(-0.5^{\circ} \mathrm{C}\right)$ is possibly less than the strength of

2 the equivalent ice-free fracture (Davies et al., 2001). In constant strain experiments, 3 where the shear velocity can increase freely, fracturing is also temperature-

4 dependent but occurs due to sudden fracturing along rock-ice interfaces for low 5 normal stress (Günzel, 2008).

6 However, the abrupt changes in rock-mechanical behaviour at the freezing point 7 have not yet been integrated in such models. This is surprising since Mellor (1973) 8 could show a drop in uniaxial compressive strength from $20-50 \%$ and, respectively, 9 a drop of the tensile strength varying from $15-70 \%$ for increasing temperatures 10 between $-10^{\circ} \mathrm{C}$ and $0{ }^{\circ} \mathrm{C}$, which was later confirmed by Dahlström (1992), Lie et al. 11 (2003) and Dwivedi et al. (1998). The most likely explanation for the strength 12 increase at low temperature is that freezing of absorbed water in pores, micro-cracks 13 and micro-fissures leads to an effective grouting of the rock. The abrupt changes in 14 rock-mechanical properties (i.e. thawing could cause a drop of rock strength by $50 \%$ 15 in a short time frame) are unparalleled by any other influence on rock strength and 16 will have serious, presently overlooked, effects on rock instability.

17 Permafrost affected rock-slope failure could also be analysed and assessed within 18 the paraglacial framework which describes the transition or adjustment of a 19 landscape from glacial conditions to non-glacial conditions (Ballantyne, 2002; 20 Slaymaker, 2009). Degrading permafrost in rockwalls is a possible explanation for 21 the response time of peak landslide activity following deglaciation (Wegmann et al., 22 1998; McColl, 2012). Paraglacial effects on rock-slope stability could act to 23 orchestrate landslide magnitude, frequency and location as well as their change 24 through glacial-interglacial cycles (Korup and Clague, 2009; Korup et al., 2010; 25 McColl, 2012). In this context, the processual and mechanical understanding of the 26 permafrost-related failure mechanisms is also a crucial issue to decipher the 
1 paraglacial impact among multiple other factors that influence rock slope stability

2 (Holm et al., 2004; McColl, 2012).

3 This paper presents a mechanical model which combines rock- and ice mechanical

4 concepts and parameterisation from a wide background of different related

5 engineering subjects. The model implications are tested by laboratory experiments

6 on untested key assumptions. The mechanical behaviour of ice-filled joints in time

7 (response time) and space (magnitude) is hypothesized based on consequent

8 reasoning. This paper addresses three questions:

9 (i) How does thawing theoretically affect rock- and ice-mechanical properties?

10 (ii) At what time scales (response time) and spatial scales (magnitudes) of

11 destabilisation do rock- or ice-mechanical processes dominate instability behaviour?

12 (iii) How can we empirically prove the critical and novel concepts of mechanical 13 destabilisation along rock-ice interfaces and along rock-rock contacts when thawing?

152 Deriving the rock-ice mechanical model

16 According to the Hoek-Brown failure criterion (Hoek and Brown, 1980) and the critical

17 path concept (Einstein et al., 1983), rock mass failure is related to two essential

18 processes: (i) time-dependent failure of intact rock bridges connecting non-persistent

19 discontinuities, often conditioned by subcritical crack growth, and (ii) shear failure of

20 discrete rock blocks overcoming frictional resistance within different material

21 combinations (Erismann and Abele, 2001). From a mechanical point of view, the

22 presence of permafrost can increase shear stress due to changing water pressure

23 and cryostatic pressure, i.e. by ice segregation. Thawing permafrost can decrease

24 shear resistance of rock masses as thawing alters the mechanical behaviour of intact

25 rock, rock-rock contacts, rock-ice contacts and ice. In this paper, all these types of 
1 failure are combined to derive a mechanical model for failure of frozen rock mass

2 (Fig 1).

3

42.1 A preliminary rock-ice mechanical model

5

6 Fig. 1: A schematic representation of the rock-ice mechanical model

7

8 The proposed model contains shear forces acting on the potential sliding plane and

9 the shear resistance provided by the frozen rock mass:

10 The shear forces are provided by:

A: Components of gravity and pre-existing stresses parallel to the shear plane

B: Hydrostatic pressure due to joints filled with water

C: Cryostatic pressure provided e.g. by ice segregation

14 The shear resistance of the ice-filled joint is provided by:

1: Creep and fracture of the ice itself

2: Failure of rock-ice contacts

3: Friction of rough fracture surfaces (rock-rock contact)

4: Fracture of cohesive rock bridges.

20 The synoptic models are based on the principle of superposition (Kemeny, 2003), i.e.

21 the shear resistance provided by one component reduces the amount of shear stress

22 applied to the other components. The processes act individually, in succession or in

23 combination. The shear stress at failure is then

$24 A+B+C=1+2+3+4$

Equ. 1 


\section{$1 \quad 2.2$ Permafrost induced shear stresses}

\section{$2 \quad$ 2.2.1 Hydrostatic pressure (B)}

3 The impact of permafrost on hydraulic permeability of rocks and water pressure has 4 rarely been investigated. Pogrebiskiy and Chernyshev (1977) conducted 5 experimental pumping and pressurization in frozen and unfrozen fissured (aperture 6 up to $10 \mathrm{~cm}$ ) granites. They found that the hydraulic permeability of frozen fissured 7 rock is one to three orders of magnitude lower than the permeability of identical 8 thawed rock. The ratio is higher for weathered rocks close to the surface with greater

9 ice contents. Perhaps most importantly, the anisotropy of the hydraulic permeability 10 of a rock mass strongly increases when freezing. The combination of perched 11 groundwater and deep-reaching unfrozen fracture systems regularly causes 12 significant problems for tunnelling structures by water inundating in permafrost rocks, 13 e.g. reported at the Kunlun tunnel of the QingHai-Tibetian railway track, at the 14 Zusgpitze cog wheel train tunnel (Germany), at the Aiguille du Midi (France) and at 15 the Jungfrau (Switzerland) (Ulrich and King, 1993; Wegmann et al., 1998; Tang and Wang, 2006; Hasler et al., 2008). Enhanced water pressures due to the sealing of 17 rock surfaces by ice can destabilise rock slopes (Terzaghi, 1962) as coupled hydro18 mechanical modelling suggests for the 1988 Tschierva rock slope failure $\left(3^{\star} 10^{5} \mathrm{~m}^{3}\right)$ 19 (Fischer and Huggel, 2008). The importance of pressurised water for rock slope 20 instabilities has also been stated where outflow was observed subsequent to failure, 21 e.g. at the scarps of Kolka-Karmadon and Mt. Steller (Haeberli, 2005; Gruber and 22 Haeberli, 2007; Huggel et al., 2008). However, no detailed empirical quantitative 23 studies exist on repository and water pressure effects in permafrost rock walls. 


\section{$1 \quad$ 2.2.2 Cryostatic pressure and ice segregation (C)}

2 Ice pressure build-up can derive from volumetric expansion of in situ water (Hall et 3 al., 2002; Matsuoka and Murton, 2008) and ice segregation (Walder and Hallet, 4 1985; Hallet, 2006; Murton et al., 2006). In the laboratory, open systems allow water 5 migration and support ice segregation, while closed water-saturated systems favour

6 volumetric expansion (Matsuoka, 1990). Ice pressure by volumetric expansion could 7 theoretically cause stresses up to $207 \mathrm{MPa}$ (Matsuoka and Murton, 2008). Ice 8 pressure can be relaxed through ice deformation and ice expansion into free spaces 9 and ice extrusion (Davidson and Nye, 1985; Tharp, 1987). These effects can lead to 10 stress reduction and contraction of frozen ice-filled rock samples in the long-term 11 (Matsuoka, 1990). Ice segregation along temperature gradients in fissured natural 12 bedrock will cause cryosuction up to several MPa (Walder and Hallet, 1985; Murton 13 et al., 2006; Matsuoka and Murton, 2008) and is likely to generate more or less 14 persistent elevated levels of cryostatic stress in permafrost rocks. Effective ice 15 segregation requires a temperature gradient for sub-zero temperatures ideally from 163 to $-6{ }^{\circ} \mathrm{C}$, water supply and an inter-crack pressure slightly above the tensile 17 strength of rock (Hallet et al., 1991). These conditions frequently occur at the base of 18 the active layer above the permafrost table (Hallet et al., 1991; Murton et al., 2006). 19 Heaving pressures of 20 to $30 \mathrm{MPa}$ exceed the tensile strength of even strong rocks 20 and can cause crack propagation (Hallet et al., 1991). For potential shear planes at 21 greater depths $(>10 \mathrm{~m})$ below ground, reduced temperature gradients and water 22 availability, combined with increased normal stress effectively counteract the 23 formation of ice and squeeze out ice between protruding rock-rock contacts over time 24 and hence reduce the importance of ice segregation. This so-called "shut off 25 pressure" for ice segregation at normal stresses higher than $200 \mathrm{kPa}$ (equivalent to 8 
1 m rock overburden) has been observed and described by Clark \& Phillips (2003),

2 Nixon (1982) and Konrad \& Morgenstern (1982).

3

$4 \quad 2.3$ Permafrost induced shear resistance

\section{$5 \quad$ 2.3.1 Creep and fracture of ice in rock joints (1)}

6 Several studies show that most subsurface fractures in Alpine permafrost bedrock

7 are ice-filled (Körner and Ulrich, 1965; Haeberli, 1992; Ulrich and King, 1993; Gruber

8 and Haeberli, 2007). This is not surprising since alpine bedrock is mostly water-

9 saturated (apart from the surface) and ice acts to attract water by cryosuction (Sass,

10 2005). Ice does not deform in a purely elastic, viscous or plastic way and, thus, does

11 not readily lend itself to classical engineering analysis in terms of "strength" and

12 "failure" (Sanderson, 1988). However, these terms have been used for a

13 straightforward characterisation of ice-mechanical properties (Sanderson, 1988;

14 Paterson, 2001). Hereafter, ice properties will be separated in ductile behaviour due

15 to elastic and plastic creep deformation without fracture and fracturing due to brittle 16 or brittle-ductile behaviour.

17 It is assumed that ice-filled discontinuities react according to stress-strain behaviour 18 of polycrystalline ice. The deformation of pure ice is characterized by four phases:

19 Elastic deformation (1) that is followed by plastic deformation, firstly at a decreasing 20 rate (2, primary creep), then at a constant rate (3, secondary creep) and finally at an 21 increasing rate (4, tertiary creep) (Budd and Jacka, 1989). Mostly secondary creep 22 and tertiary creep occur at speeds relevant for active mass movements. The flow 23 relation (Glen's Law) for secondary creep relates the shear strain rate $\varepsilon$ '

$24 \quad \varepsilon^{\prime}=A \tau^{n}$

Equ. 2 
1 to the shear stress $\tau$, where the Arrhenius factor $A$ depends mainly on ice

2 temperature, crystal size and orientation, impurity content and water content in the

3 ice (Paterson, 2001). The exponent $n$ is usually assumed to be 3 in ice-sheet

4 modelling at axial stresses between 0.2 and 2 MPa (Paterson, 2001; Schulson and

5 Duval, 2009). Crystal orientation, impurity content and shear stresses remain more or

6 less constant over short timescales. In contrary, ice temperature and water content in

7 mass movement systems are subject to major annual and interannual changes. The

8 factor $A$ can be approximated by the Arrhenius relation, which can be used at all

9 temperatures (Paterson, 2001). For temperatures above $-10{ }^{\circ} \mathrm{C} A$ can be

10 approached by

$11 A=A_{0} \exp \left(-\frac{Q}{R T}\right) \approx A_{0} \exp \left(-\frac{16700}{T_{k}}\right)$

Equ. 3

12 where $A_{0}$ is independent of temperature, $R$ is the universal gas constant and $Q$ is the 13 activation energy (Weertman, 1973). The T-dependency of $A$ is partly counteracted 14 by the T-dependency of $Q$ which increases at $T>-10{ }^{\circ} \mathrm{C}$ (Schulson and Duval, 15 2009). But this seems to be negligible, since empirical values show a strong increase 16 of $A$ with $\mathrm{T}$ from $4.9^{*} 10^{-6}\left[\mathrm{~s}^{-1}(\mathrm{kPa})^{-3}\right]$ at $-10{ }^{\circ} \mathrm{C}$ over $24^{*} 10^{-6}\left[\mathrm{~s}^{-1}(\mathrm{kPa})^{-3}\right]$ at $-2{ }^{\circ} \mathrm{C}$ to $1768^{*} 10^{-6}\left[\mathrm{~s}^{-1}(\mathrm{kPa})^{-3}\right]$ at $0{ }^{\circ} \mathrm{C}$ (Paterson, 2001). $A_{0 t}$ for tertiary creep

$18 A_{0 t}=(3.2+5.8 \mathrm{~W}) \times 10^{-15}(\mathrm{kPa})^{-3} \mathrm{~s}^{-1} \quad$ Equ. 4

19 can be related to the water content $W[\%]$. Paterson (2001) states that $-2{ }^{\circ} \mathrm{C}$ is the 20 lowest temperature at which a sufficient amount of water exists in the ice to affect the 21 stress-strain behaviour. Equ. 3 and Equ. 4 show, that both, ice temperature and 22 water content play a dominant role for the mechanical behaviour of ice-filled joints at 23 temperatures close to $0^{\circ} \mathrm{C}$. Assuming a moderate water content of $0.6 \%$ at $0{ }^{\circ} \mathrm{C}$, the 24 creep rate at $0{ }^{\circ} \mathrm{C}$ is three times the rate at $-2{ }^{\circ} \mathrm{C}$ (Paterson, 2001). 
1 Exceeding the thresholds for stress, strain or strain rate (for uniaxial compression this

2 is $5-10 \mathrm{MPa}, 1 \%$ and $10^{-3} \mathrm{~s}^{-1}$, respectively), ice deforms in a brittle and ductile-brittle

3 manner after seconds to minutes until complete fracture occurs (Sanderson, 1988).

4 Tensile fracturing can already occur at 1-2 MPa. As $1 \mathrm{MPa}$ equals the normal stress

5 of $40 \mathrm{~m}$ rock overburden, one could expect that fracturing phenomena may only

6 influence high-magnitude rockslides. However, stress is very unequally distributed in

7 unstable rocks (Eberhardt et al., 2004) and thus tensile and compressive stresses in

8 the range of $1 \mathrm{MPa}$ (equals gravitational force of $10 \mathrm{~kg}$ on a $\mathrm{cm}^{2}$ ) can exist locally

9 even in rockslides of a few meters thickness. On the other hand, Renshaw \&

10 Schulson (2001) and Sanderson (1988) showed that both, rock and ice materials

11 tend to react rather ductile than brittle under high confinement.

\section{$13 \quad$ 2.3.2 Failure of rock-ice contacts (2)}

14 For a lower thickness of the detachment layer and for high deformation rates, the 15 detachment of the rock-ice interface is more likely than the failure of the ice itself. 16 Shearing experiments using concrete-ice samples under constant strain show that for 17 normal load up to ca. $300 \mathrm{kPa}$ (equivalent to $12 \mathrm{~m}$ rock overburden), the failure 18 occurs at the concrete-ice interface and not within the ice (Günzel, 2008). In constant 19 stress experiments, where the rate of deformation can accelerate freely, all 20 experiments simulating up to $630 \mathrm{kPa}$ (25 m overburden) caused a detachment of 21 the rock-ice interface (Günzel, 2008). Thus, we used the constant stress experiments 22 as a representation of rock-ice detachment processes; the development of the 23 formula dependent on normal load and temperature is described in a section 4.1 .. 
$1 \quad$ 2.3.3 Friction along rock fractures (rock-rock contact) (3)

2 The influence of ice and low temperatures on the frictional behaviour of rock fractures

3 has not been investigated yet. However, a significant change must be expected when

4 combining the rock friction theory (Equ. 5) with empirical findings on the rapid change

5 of intact rock strength at the freezing point (see below). The peak shear strength of

6 separated rock blocks along a rough joint can be expressed as

$7 \tau_{p}=\sigma^{\prime} \tan \left(J R C \times \log _{10}\left(\frac{\sigma_{u}}{\sigma^{\prime}}\right)+\varphi_{r}\right) \quad$ Equ. 5

8 where $\tau_{p}$ is the peak shear strength, $\sigma^{\prime}$ is the effective normal stress, $J R C$ is the joint

9 roughness coefficient, $\sigma_{u}$ is the joint wall compressive strength and $\varphi_{r}$ is the residual

10 friction angle of a smooth unweathered rock surface (Barton and Choubey, 1977).

11 For saturated intact rock, Mellor (1973) could show a drop in uniaxial compressive 12 strength from $20 \%$ (Barre Granite, porosity $p=1.2 \%$ ) to $50 \%$ (Berea Sandstone, $p$ $13=20 \%$ ) and, respectively a drop of the tensile strength varying from $15 \%$ to $70 \%$ for 14 increasing temperatures between $-10{ }^{\circ} \mathrm{C}$ and $0{ }^{\circ} \mathrm{C}$ (see also Dahlström, 1992;

15 Dwivedi et al., 1998; Li et al., 2003). The loss of strength correlates with rock porosity 16 and water content, is more pronounced for tensile strength than for compressive 17 strength and corresponds to changes in Poisson's ratio, Young's modulus and the 18 joint stiffness (Inada and Yokota, 1984; Glamheden, 2001).

19 The increase of the uniaxial compressive strength $\left(\sigma_{u}\right.$ in Equ. 5) under frozen 20 conditions increases the peak shear strength due to an inhibited shearing of 21 asperities. Thus, the friction of rock joints is presumably higher under frozen 22 conditions than under unfrozen conditions even for rock-rock contacts without ice 23 intercalation. This effect should be more pronounced for rougher fractures with a 24 higher JRC. 


\section{$2 \quad$ 2.3.4 Fracture of intact rock bridges (4)}

3 The susceptibility of rock bridges to fracturing will increase in thawing rock. Failure of

4 intact rock bridges occurs due to both critical and subcritical crack growth (Atkinson,

5 1982). Critical crack growth occurs when the stress intensity factor $K$ exceeds the

6 fracture toughness $K_{C}$ (Irwin, 1958). Subcritical crack growth occurs even when $K_{C}<$

$7 \quad K$ and is time-dependent. Conceptualising an individual rock bridge as a patch of

8 intact material between two coplanar cracks, $K_{I I}$ can be incorporated in the cohesion

9 term of the Coulomb failure criterion (Kemeny, 2003)

$10 \tau_{p}=\frac{K_{I I} \sqrt{\pi a}}{2 w}$ with $K_{I I}=\frac{\tau 2 w}{\sqrt{\pi a}}$ and $K_{I I}=K_{I I C} \quad$ for $\tau=\tau_{p} \quad$ Equ. 6

11 where $K_{I I C}$ is the Mode II fracture toughness, $K_{I I}$ is the Mode II stress intensity factor,

$12 a$ is the half width of the rock bridge, $2 w$ is the bridge-to-bridge spacing, and $\tau_{p}$ is the

13 peak shear strength.

14 Freezing of water-saturated intact rock enhances the fracture toughness. Fracture 15 toughness increases by $8 \%$ for dolerite $(p=0,5 \%)$ and by $37 \%$ for fine-grained sandstone $(p=5 \%)$ samples when freezing to $-10{ }^{\circ} \mathrm{C}$ dependent on moisture

17 content and temperature (Dwivedi et al., 1998; Dwivedi et al., 2000). Pressure18 maintained solutions at the crack tips in greater depths promote chemical activity and 19 possibly enhance fatigue effects when frozen rock is thawing (Whalley, 1982). 20 Studies on P-wave velocity suggest that the most pronounced change in fracture 21 toughness occurs close to the equilibrium freezing point as has been shown for 22 compressive and tensile strength in earlier studies (Mellor, 1973). P-wave velocity is 23 the highest correlated proxy to Mode I fracture toughness $\left(R^{2}\right.$ of 0.8$)$ and Mode I and 24 II fracture toughness correlate closely (Chang et al., 2002). P-wave velocities of 22 
1 arctic and alpine low-porosity bedrock samples were shown to increase by a factor of

2 1.1-2.6 subsequent to freezing mostly between the equilibrium freezing point with a

3 mean of $-0.5^{\circ} \mathrm{C}$ and $-3^{\circ} \mathrm{C}$ (Draebing and Krautblatter, 2012).

4

\section{The rock-ice mechanical model}

6 The frictional resistance of rock can thus be formulated as:

$7 \quad\left|\tau_{p}\right|=\varepsilon_{w} / A_{0} \exp \left(-\frac{16700}{T_{K}}\right) \quad$ Secondary creep of ice (Equ. $\left.2+3\right)$

$8+\left(-144 * T_{C}+0.42 * \sigma^{\prime}+41.3\right) \quad$ Failure of rock-ice contact (Equ. $7+8$, see 4.1 .3$)$

$9+\sigma^{\prime} \tan \left(J R C^{*} \log _{10}\left(\frac{\sigma_{u}}{\sigma^{\prime}}\right)+\varphi_{r}\right) \quad$ Friction of rock-rock contacts (Equ. 5)

$10+\frac{K_{C} \sqrt{\pi a}}{2 w} \quad$ Fracturing of rock bridges (Equ. 6)

11 where the critical fracture toughness $K_{c}$, the uniaxial compressive strength $\sigma_{c}$ and

12 temperature $T_{c}\left[{ }^{\circ} \mathrm{C}\right]$ and $T_{K}[\mathrm{~K}]$ are the sensitive parameters to warming. This 13 equation explains why rock fracturing, rock friction, creep of ice and failure of rock ice 14 contacts will heavily respond to changes of $K_{c}$ up to $40 \%$ and to changes of $\sigma_{c}$ up to $1550 \%$ (Mellor, 1973; Dwivedi et al., 2000) and temperature changes $\left(T_{C}\right.$ and $\left.T_{K}\right)$ when 16 thawing. This basic equation could then be adapted to specific conditions. 17 Adaptations could be necessary (i) to reflect the geometry and failure mode of rock 18 bridges, (ii) and to specify the type of deformation of the ice inside the rock fracture.

19 Moreover, the equations reflecting friction and failure of rock-ice contacts need to be 20 generalized as they yet reflect only certain types of contact geometries and 21 mechanical behaviour. 


\subsection{Instability in time: initiation and acceleration of instability}

3 Assuming that initial deformations destructing rock bridges are (i) too slow to cause

4 ice fracture and failure of rock-ice contacts (strain rate threshold see Sanderson,

5 1988) and (ii) are too slow to allow creep deformation of ice take up significant

6 amounts of stress (strain-dependent shear resistance Equ. 2), the failure criterion for

7 the preparation of new sliding planes is

$8 \quad|\tau|=\sigma^{\prime} \tan \left(J R C^{*} \log _{10}\left(\frac{\sigma_{u}}{\sigma^{\prime}}\right)+\varphi_{r}\right)$

$9+\frac{K_{C} \sqrt{\pi a}}{2 w}$

(Equ. 6)

10 where $\sigma_{u}$ and $K_{c}$ decrease significantly between $-5{ }^{\circ} \mathrm{C}$ and $0{ }^{\circ} \mathrm{C}$. Thus, slow initial

11 destabilisation is likely to occur due to changes in rock friction and fracturing. The

12 failure of single rock bridges will create a positive feedback as more shear stress is

13 then applied to the remaining rock bridges. After the destruction of cohesive rock

14 bridges, the acceleration of dislocations along the thawing fracture is governed by

$15|\tau|=\varepsilon_{w} / A_{0} \exp \left(-\frac{16700}{T_{K}}\right)$

(Equ. $2+3)$

$16+\left(-144 * T_{C}+0.42 * \sigma^{\prime}+41.3\right)$

(Equ. $7+8)$

$17+\sigma^{\prime} \tan \left(J R C^{*} \log _{10}\left(\frac{\sigma_{u}}{\sigma^{\prime}}\right)+\varphi_{r}\right)$

(Equ. 5)

18 where an increase in $T_{K}$ decreases the amount of shear stress that is "absorbed" by

19 the creep deformation of ice. Thus, faster deformations are controlled by the creep of 20 ice, the propensity for rock-ice detachments and the friction of rock-rock contacts.

21 The amount of stress absorbed by the total friction at rough fracture surfaces 
1 decreases with warming due to declining compressive rock strength. An increase of

$2 T_{c}$ facilitates the failure of ice in rock joints. The warming of permafrost rock masses

3 between $-5{ }^{\circ} \mathrm{C}$ and $0{ }^{\circ} \mathrm{C}$ promotes both, the slow progressive development of new

4 shear planes, controlled by rock mechanics, and, subsequently, the accelerating 5 failure along predefined sliding planes that is increasingly controlled by ice6 mechanics.

7

$8 \quad 3.2$ Instability in space: the magnitude effect

9

Fig. 2: The efficiency of shear force and shear resistance with depth of the shear plane.

12 The spatial differentiation of processes controlling rock slope stability, i.e. with normal 13 stress, is a classical concept in rock instability research (Terzaghi, 1962; Whalley, 14 1984). The efficiency of all processes outlined above varies with normal stress (Fig. 15 2). Some processes are more pronounced for shallow (low-magnitude) rock slope 16 failures, others are more pronounced for deep-seated (high-magnitude) rock slope 17 failures. While water pressure exists at all depths, there is a "shut off" pressure for ice 18 segregation that is approximately equivalent to 20 m rock overburden (Nixon, 1982; 19 Clark and Phillips, 2003). The same has been reported for rock-ice detachments. In 20 constant stress experiments, all experiments simulating up to $630 \mathrm{kPa}(25 \mathrm{~m}$ 21 overburden) caused a detachment of the rock-ice interface (Günzel, 2008). Rock-ice 22 detachments and fracturing of ice itself are suppressed in favour of creep of ice at 23 greater depths, i.e. higher confining pressures (Sanderson, 1988). In contrast, the 24 contribution of rock friction and fracturing to the overall stability tends to increase with 25 higher normal stress (Section 4.3.2). Thresholds needed for the initiation of fracturing 
1 along critical paths are often not reached in shallow depths (Eberhardt et al., 1999).

2 In conclusion, ice-mechanical processes are important for shallow (low-magnitude)

3 rock slope failure with a depth of the shear plane below $20 \mathrm{~m}$, while rock-mechanical

4 processes might dominate deep seated (high-magnitude) rock slope failure in

5 warming permafrost rocks close to thawing.

6

74 Validation of the rock-ice mechanical model - laboratory experiments

9 The rock-ice mechanical model described above is derived from empirical studies on

10 the effect of ice on rock mechanical parameters and their application on established

11 rock- and ice-mechanical concepts on friction and fracturing. Laboratory experiments

12 were conducted to validate the general performance of frictional und fractional

13 processes in a thawing rock fracture.

\section{$14 \quad 4.1$ Shear strength of rock-ice interfaces}

15 Some of the findings reported here were described in a conference paper (Günzel,

16 2008). However, the exact layout and the development of a general temperature and

17 stress-dependent failure criterion has not been reported before.

\section{$18 \quad$ 4.1.1 Methods}

19 Shear experiments were carried out under constant strain and constant stress, which 20 represents a boundary condition similar to the constant stress situation in natural 21 slopes (Günzel, 2008). To simulate the natural and reproducible roughness of the 22 rock joints, samples were made of high-strength concrete (Densit Ducorit D4) with a 
1 regular saw-tooth surface. The saw-teeth had an angle of $20^{\circ}$ and amplitude of 1.0 $2 \mathrm{~mm}$ (Fig. 3).

3

4 Fig. 3: Dimensions of the saw-tooth surface

5

6 Two sample types were used to simulate different infill thickness: concrete-ice

7 samples and sandwich samples. The concrete-ice samples consist of a concrete

8 block with saw-tooth surface overlain by an equally thick ice block. This sample type

9 simulates an ice filled joint with the ice thickness being much larger than the

10 amplitude of the surface roughness. The concrete-ice samples are prepared by

11 placing the concrete block into a mould filled with water and allowing it to freeze.

12 The sandwich samples consist of two saw-tooth concrete blocks with a $1 \mathrm{~mm}$ thick

13 layer of ice in between. This sample type simulates an ice thickness equal to the

14 amplitude of the surface roughness. For preparation, the two concrete blocks are

15 immersed in water in a mould (Fig. 4a). A bolt is glued to the top block which passes

16 through a bar across the mould. The top block is then lifted by turning the nut against

17 the bar while the movement is measured with an LVDT (Linear variable differential

18 transformer). After that the surplus water on top of the sample is drained and the 19 sample is frozen.

20 Temperatures inside the sample was measured with a thermocouple cast into the 21 concrete block; the sensitive tip is located a small cavity in the centre of the sample.

22 Tests were carried out in a $60 \mathrm{~mm} \times 60 \mathrm{~mm}$ direct shear box modified with a pulley 23 system and weights to apply a constant shear stress to the samples (Fig. 4b). Normal 24 stress between 135 and $620 \mathrm{kPa}$ were also provided by hanging weights. Horizontal 25 and vertical displacements were measured with LVDTs, the shear stress was 26 measured with a load cell. After applying both normal and shear stress the sample 
1 temperature was kept below $-4^{\circ} \mathrm{C}$ in a cold room for several hours before increasing

2 it at a rate of approximately $0.3^{\circ} \mathrm{C}$ per hour until the sample failed.

3

4 Fig. 4: a) Preparation of sandwich sample; b) Schematic overview over experimental set-up

5 of the constant stress tests

\section{$6 \quad 4.1 .2$ Results}

7 The results for concrete-ice samples and sandwich samples are very similar and we

8 will hereafter refer to concrete ice samples results as shown in Fig. 5 (plotted against

9 time) and Fig. 6 (plotted against horizontal displacement). The decrease of stress

10 during the test is due to friction in the pulley system and the apparent change of the

11 rate of temperature increase in Fig. 6 is due to the increasing rate of horizontal

12 deformation immediately before failure of the sample.

13 The horizontal displacement during the constant stress tests was considerably slower

14 than during the constant strain tests, it varied between $0.002 \mathrm{~mm} / \mathrm{hr}$ and $0.06 \mathrm{~mm} / \mathrm{hr}$.

15 The deformation rate increased with increasing shear stress but no significant 16 change could be observed for increasing normal stress or temperature. The

17 horizontal displacement at failure was between $1.5 \mathrm{~mm}$ and $2.5 \mathrm{~mm}$, similar to the 18 displacement at failure of the constant strain tests. The vertical displacement 19 decreased with increasing normal stress.

21 Fig. 5: Results of a constant stress experiment (concrete-ice sample, normal stress $=207$ $22 \mathrm{kPa}$ ) plotted against time.

25 Fig. 6: Results of a constant stress experiment (concrete-ice sample, normal stress $=207$ $26 \mathrm{kPa}$ ) plotted against horizontal displacement. 


\section{$1 \quad 4.1 .3$ Discussion}

2

3 Fig. 7: Shear stress at failure plotted against failure temperature for constant-stress tests 4 with concrete-ice samples.

6 Fig. 7 shows the shear stresses at failure plotted against the temperature at failure 7 for normal stresses between $136 \mathrm{kPa}$ and $633 \mathrm{kPa}$. In constant stress experiments, 8 the shear stress at failure $\tau_{f}$ is not a peak shear stress $\tau_{\mathrm{p}}$ in the strict sense. A clear 9 linear relationship can be observed between the shear strength and the failure 10 temperature for each normal stress value. The slopes of the linear relationships are 11 very similar with values between -126 and $-151 \mathrm{kPa} /{ }^{\circ} \mathrm{C}$. In Fig. 7 the trend-lines were 12 forced to the same average slope of $-144 \mathrm{kPa} /{ }^{\circ} \mathrm{C}$ slightly reducing the average 13 correlation coefficient to $0.94-0.95$. The trend-lines were the basis for Fig. 8 which 14 shows the linear relationship of the shear stress vs. normal stress at $0{ }^{\circ} \mathrm{C}$. The only exception is the value for the lowest normal stress (136 kPa).

Fig. 8: Linear relationship of shear stress at failure vs. normal stress for constant stress tests 18 for $0^{\circ} \mathrm{C}$.

20 The linear relationships in Fig. 7 and Fig. 8 are now used to formulate a general 21 equation for the shear strength of the rock-ice contact:

$22 \tau_{f}=144 * T_{C}+\tau_{0}$ Equ. 7

23 where $T_{C}\left({ }^{\circ} \mathrm{C}\right)$ is the is the temperature of the ice at failure, $\tau_{f}$ is the shear stress at 24 failure and $\tau_{0}$ is the shear strength at $0{ }^{\circ} \mathrm{C}$. The value of $\tau_{0}$ is approximated from Fig. 25 8: 
$1 \quad \tau_{0}=0.42 * \sigma^{\prime}+41.3$

Equ. 8

34.2 Frictional strength of rock-rock surfaces

4 Changes in frictional properties of frozen rocks have not been mentioned in the

5 literature before but can be deduced from theoretical considerations provided in

6 Section 2.3.4. Here, we provide a new lab experiment to test the general assumption

7 based on 40 carefully designed friction tests in a freezing chamber.

\section{$8 \quad 4.2 .1$ Methods}

9 Three direct shear tests series on rock samples of two different lithologies were

10 conducted. These test whether peak shear strength of a rock joint at a given

11 roughness is higher under frozen conditions than under unfrozen conditions even if

12 no ice is present in the joint; and determine the controlling factors of the shear

13 strength. These benchmark tests are preliminary and intend to validate the general

14 assumption of Equ. 5.

15

16 Experimental setup

17 Samples of two similar lithologies (Wetterstein limestone [L1, L2] and Wetterstein 18 dolomite [D1]) were taken from the Zugspitze permafrost summit (Germany/Austria).

19 These have a homogeneous, isotropic fine-grained texture which predestines them

20 for rock-mechanical experiments similar to the Solnhofen limestone (Miller, 1961).

21 Three pairs of cuboid samples were produced with a thickness of $10-15 \mathrm{~mm}$ and a 22 shear plane of $35 * 35 \mathrm{~mm}$. Samples were fitted tightly into a customised steel 23 specimen holder of the shear frame. The specimens were saturated under 24 atmospheric pressure to reproduce natural conditions (Krus, 1995; Sass, 2005). The 
1 roughness of the shear plane was generated using an abrasive paper with a grit of

224 grains per inch similar to joint roughness coefficients also found in actively

3 displacing fractures at the Zugspitze. The roughness was generated unidirectional

4 which results in an irregular saw tooth pattern with a maximum amplitude and wave

5 length equivalent to the paper grain size of $764 \mu \mathrm{m}$. The specimens were cleaned

6 after sanding in an ultrasonic bath to free them from loose particles.

7 For the shear test, a modified direct shear device providing a maximum shear load of

$85 \mathrm{kN}$ was used. The direct shear box is placed in a thermally isolated freezing

9 chamber. Cooling is provided by a plate cooler which is controlled by an external $\mathrm{Pt}$

10100 temperature sensor placed close to the sample. The cold air is removed from the

11 cooler plate using a 3-channel enforced chilling system and transported to the

12 thermally isolated shear device via a high-performance ventilation system. Within the

13 shear box chamber, minimum air temperatures below $-10^{\circ} \mathrm{C}$ can be achieved and

14 the sample temperature can be controlled with an accuracy of $0.5^{\circ} \mathrm{C}$. The specimen

15 was sheared at a given normal load under frozen and subsequently under unfrozen

16 conditions at a constant velocity of $1 \mathrm{~mm} / \mathrm{hr}$. Shearing was stopped after a shear

17 displacement of at least $6 \mathrm{~mm}$. Between the tests, each specimen was re-saturated

18 and initial roughness was reconditioned. Frozen tests were conducted at a specimen

19 temperature at $-4.5( \pm 0.5){ }^{\circ} \mathrm{C}$ to guarantee the frozen state of the specimen. A drying

20 agent was applied to extract the moisture from the air inside the shear frame

21 chamber. This method prevented the formation of an ice layer on the shear plane.

22 The normal load of 74 and $1333 \mathrm{kPa}$ was applied after freezing to avoid the crushing

23 of asperities by uniaxial compression before the desired testing conditions were

24 attained. 


\section{$1 \quad 4.2 .2$ Results}

2 More than 40 shear tests à 6 to $10 \mathrm{hrs}$ were conducted using three different sample-

3 pairs. The shear test results from the three test series are visualized by shear 4 strength - normal stress diagrams in Fig. 10a (D1 - dolomite), Fig. 10b (L1 5 limestone) and Fig. 10c (L2 - limestone). For all three test series the angle of friction

6 is higher for frozen tests $\left(\varphi_{\mathbf{\Lambda}}\right)$ than for unfrozen tests $\left(\varphi_{\Perp}\right)$. The difference in the angle

7 of friction between frozen and unfrozen tests is $4.6^{\circ}$ for specimen $L 1,6.4^{\circ}$ for

8 specimen $\mathrm{L} 2$ and $4.4^{\circ}$ for specimen D1. It is remarkable that for all three test series

9 there is practically no difference in shear strength between frozen and unfrozen tests

10 below normal stresses of about $400-600 \mathrm{kPa}$ which corresponds to the expectations

11 according to the dilatation-shearing of asperities transition developed by Patton

12 (1966). An increase of shear strength due to freezing is obvious for higher normal

13 stresses ( $500-1400 \mathrm{kPa})$ and the mean absolute peak values of frozen rock friction

14 increase as much as 65 to $160 \mathrm{kPa}(14-17 \%)$ in comparison to unfrozen values.

16 Fig. 9a-c: Peak shear strength - normal stress relationships for direct shear tests on the 17 dolomite sample (D1) and limestone samples (L1, L2) performed with constant velocities.

18

\subsubsection{Discussion}

The shear strength - normal stress relationships display a clear linear behaviour $\left(\mathrm{R}^{2}\right.$ $>0.94$ ) and a clear difference between frozen and unfrozen test results above 500 $\mathrm{kPa}$ for all three test series. Even though the differences are not very large, they are consistent and, given to the small roughness of the samples, they perform in the range of expected values. To account for the accurate description of the friction angle, we carefully discuss all potential sources of noise: 
$1 \quad$ 3.2.3.1. Potential errors

2 Machine errors: Changes in frictional properties of the shear machine due to

3 temperature changes and freezing were evaluated using dummy samples prior to the

4 experiments. This error was systematically corrected in all measurements.

5 Specimen errors: For the entire test series the same specimens were used with the 6 same orientation within the shear frame to reduce the effects of material

7 inhomogeneity and variances in sample production. The grain size of the sanding 8 paper and the orientation of the roughness pattern were kept constant to omit the 9 effect of inconsistent roughness geometry. While a perfect replication of the initial 10 geometry is impossible the mean roughness geometry is identical for all tests and the 11 spacing of asperities remains constant $(764 \mu \mathrm{m})$.

12 Ice influence: A drying agent was used to extract moisture from the experimental set13 up to guarantee that no ice develops on the shear plane. Furthermore, samples were 14 checked after each test for ice-bonding and tests were repeated when an ice layer 15 was observed on the shear plane.

$17 \quad$ 3.2.3.2. Explanatory power

18 Role of roughness: The failure mode of a joint is always a mixture of dilation and 19 shearing of asperities (Barton and Choubey, 1977). Shearing is enhanced when the 20 relation of the joint wall compressive strength $\left(\sigma_{u}\right)$ to the effective normal load $\left(\sigma^{\prime}\right)$ 21 (Equ. 5) is reduced. This reduction can be very sudden due to a change in the 22 thermal state from unfrozen to frozen (Mellor, 1973). A decrease in shear strength 23 due to thawing can only be caused by the enhanced shearing of asperities, as this is 24 the only rock-mechanical change in the system [see 2.3.3]. Given the small scales of 25 roughness used in the tests, we expected small but well reproducible changes in 26 friction. This is due to the high statistical number of small asperities (spacing $764 \mu \mathrm{m}$ ) 
1 that are susceptible to shearing along the joint. At a higher roughness, the thawing

2 decrease in friction is expected to be more significant, but more difficult to reproduce

3 in the laboratory.

4 Role of compressive strength: The effect of strength increase due to freezing is 5 dependent on the number of flaws which can be sealed (Inada and Yokota, 1984;

6 Glamheden, 2001). Consequently, for highly -porous or stressed asperities enhanced

7 failure is expected. In the present experiments, we used low-porous rock samples

8 ( $\sim 2 \%$ effective porosity). A moderate decrease of intact rock strength when thawing

9 is expected similar to the reported change in fracture toughness $<37 \%$ for a $2.7 \%$

10 porosity limestone (Dwivedi et al., 2000).

11 These theoretical considerations support the test results which are in the range of

12 expected values. We expect an elevated decrease of friction due to thawing for

13 higher roughness, a higher degree of fissuring or a higher porosity. We think that the

14 present friction data provides a good indication that Equ. 5 is an appropriate model

15 for the mechanical description of thawing rock fractures, but this statement can be

16 asserted by a broader experimental test-series in the future.

\subsection{Discussion of the rock-ice mechanical model}

The rock-ice mechanical model presented above is based on fundamental rock- and

20 ice-mechanical principles and experimental testing of geotechnical properties under

21 frozen conditions. The novel preliminary but comprehensive model criterion covers

22 the most important mechanical processes controlling rock-slope stability.

23 For instance, infilling in rock discontinuities may control the shear strength when the

24 infill thickness-roughness ratio becomes critical (Goodman, 1970; Indraratna et al., 25 2005). Thus, grain size distribution of the filling material and failure of the infill-rock 
1 interface become important (de Toledo and Freitas, 1993; Indraratna et al., 2005).

2 Günzel (2012) shows that rock joints with frozen (sandy) infill material indicate higher

3 peak shear strength and a stronger temperature-dependency than observed for pure

4 ice. Arenson et al. (2007) concluded that the volumetric ice content and strain rate

5 are key factors for the strength characteristics of dirty ice. Ice bonding between

6 particles provides cohesion resulting in a stiffer behaviour at the beginning of

7 shearing at low confining stress. At strain rates high enough to prohibit healing of the

8 ice matrix, the residual shear strength of frozen soil is similar to that of unfrozen soil.

9 At strain relaxation, the ice-bonding heals itself due to refreezing and causes a

10 strengthening of the sample (Arenson and Springman, 2005).

11 The rock-ice mechanical model might also contribute to a different understanding of 12 the paraglacial concept (Ballantyne, 2002). While the impact of climate signals on 13 pre-existing stress-patterns due to regional tectonic input is increasingly disregarded 14 (McColl, 2012), new explanations are needed for the long response time (millennia) 15 between Lateglacial glacier retreat and the culmination of large rock slope failures in 16 Alpine regions (Prager et al., 2008). Our model is capable of explaining both, (i) the 17 slow external control, conditioned by the gradual and presumably cyclic 18 warming/thawing of Alpine rock walls over millennia in the Lateglacial/Holocene 19 period (Noetzli and Gruber, 2009), and (ii) the slow internal response, determined by 20 the gradual decrease in mechanical strength which onsets long-term fracture 21 propagation and acceleration of rock slope failure. Perhaps most important, it 22 explains why all magnitudes of rock slope failures can be prepared and triggered by 23 permafrost degradation, why higher magnitudes were ruled out in previous ice24 mechanical attempts. The rock-ice mechanical model is a step towards the 25 framework demanded by Whalley (1984) for a combined mechanical, geotechnical 26 and geomorphological stability analysis and process study amalgamating spatial, 
1 temporal and magnitude effects together reminiscent of combined effects of rock and

2 ice mechanics.

3

45 Conclusions

5 A failure criterion for permafrost rock masses has been developed which represents

6 creep of ice in an ice-filled rock joint, failure of rock-ice contacts, friction of rough

7 fracture surfaces, and fracture of cohesive rock bridges. Analysing the temporal and

8 spatial dimensions of the relevant processes, several spatial and temporal

9 implications for rock slope deformations due to thawing permafrost can be

10 suggested:

11 During slow deformations along critical paths with cohesive rock bridges, warming

12 influences the total friction and the fracture toughness of rock bridges (Model I).

13 During fast deformations along existing shear planes, warming influences the creep

14 of ice, the propensity of rock-ice detachments and total friction (Model II). Model I

15 accounts for slow subcritical destabilisation of degrading permafrost rock slopes over

16 months to millennia, subsequent to the warming impulse (relaxation time). Model II

17 explains the rapid response of rockslides to warming that occurs along existing shear

18 planes over days to months (reaction time). High magnitudes $(>20 \mathrm{~m}$ thick

19 detachment layer) can only be explained by rock-mechanical changes (Model I) while

20 for smaller magnitudes ice-mechanical processes might become more important

21 (Model II).

22 Essential elements of this failure criterion could be validated by new laboratory 23 experiments on joint friction under frozen conditions. It could be demonstrated for the 24 first time that friction of rock joints without ice infill decreases by approximately $15 \%$ 25 subsequent to thawing. Furthermore, we develop a laboratory-based model that 
1 relates rock-ice detachments in ice filled joints to normal stress and temperatures

2 between -5 and $-0.5^{\circ} \mathrm{C}$.

3 A quantitative rock-ice-model is presented that relates the destabilisation of thawing

4 permafrost rocks to temperature-related effects on both, rock- and ice-mechanics

5 and shows their applicability in time and space. Our model is capable of explaining

6 the long paraglacial response time to cyclic warming of Alpine rock walls over

7 millennia in the Lateglacial and Holocene.

8

\section{Bibliography}

Allen, S.K., Gruber, S., Owens, I.F., 2009. Exploring Steep Bedrock Permafrost and its Relationship with Recent Slope Failures in the Southern Alps of New Zealand. Permafrost and Perigl. Process. 20, 345-356.

Arenson, L., Springman, S., 2005. Triaxial constant stress and constant strain rate test on ice-rich permafrost samples. Can. Geotech. J. 42, 412-430.

Arenson, L., Springman, S., Sego, D.C., 2007. The rheology of frozen soils. Applied Rheology 17, 1-14.

Atkinson, B.K., 1982. Subcritical crack propagation in rocks: theory, experimental results and applications. J. Structural Geology 4, 41-56.

Ballantyne, C.K., 2002. Paraglacial geomorphology. Quaternary Science Reviews 21, 1935-2017.

Barton, N., Choubey, V., 1977. The shear strength of rock joints in theory and practice. Rock Mechanics 10, 1-54.

Bottino, G., Chiarle, M., Joly, A., Mortara, G., 2002. Modelling rock avalanches and their relation to permafrost degradation in glacial environments. Permafrost and Periglac. Process. 13, 283-288.

Brommer, C., Phillips, M., Keusen, H.-R., Teysseire, P., 2009. Bauen im Permafrost; Ein Leitfaden für die Praxis. Eidg. Forschungsanstalt für Wald, Schnee und Landschaft WSL, Birmensdorf.

Budd, W.F., Jacka, T.H., 1989. A review of ice rheology for ice-sheet modeling. Cold Regions Science and Technology 16, 107-144.

Chang, S.-H., Lee, C.-I., Jeon, S., 2002. Measurement of rock fracture toughness under modes I and II and mixed-mode conditions by using disc-type specimens. Engineering Geology 66, 79-97.

Clark, J.I., Phillips, R., 2003. Centrifuge modelling of frost heave of arctic gas pipelines. In: Phillips, M., Springman, S., Arenson, L. (Eds.), Permafrost - 8th International Conference. AA Balkema, Zurich, Switzerland.

Dahlström, L.-O., 1992. Rock Mechanical Consequences of Refrigeration. Chalmers University of Technology, Göteborg.

Davidson, G.P., Nye, J.F., 1985. A Photoelastic Study of Ice Pressure in Rock Cracks. Cold Reg Sci Technol 11, 141-153. 
Davies, M.C.R., Hamza, O., Harris, C., 2001. The effect of rise in mean annual temperature on the stability of rock slopes containing ice-filled discontinuities. Permafrost and Perigl. Process. 12, 137-144.

Davies, M.C.R., Hamza, O., Harris, C., 2003. Physical modelling of permafrost warming in rock slopes. In: Phillips, M., Springman, S., Arenson, L. (Eds.), 8th Int. Con. on Permafrost. Balkema, Zürich, pp. 169-174.

Davies, M.C.R., Hamza, O., Lumsden, B.W., Harris, C., 2000. Laboratory measurements of the shear strength of ice-filled rock joints. Annals of Glaciology 31, 463-467.

de Toledo, P.E.C., Freitas, M.H., 1993. Laboratory testing and parameters controlling the shear strength of filled rock joints. Geotechnique 42, 1-19.

Draebing, D., Krautblatter, M., 2012. P-wave velocity changes in freezing hard lowporosity rocks: a laboratory-based time-average model. The Cryosphere.

Dramis, F., Govi, M., Guglielmin, M., Mortara, G., 1995. Mountain Permafrost and Slope Instability in the Italian Alps: the Val Pola Landslide. Permafrost and Perigl. Process. 6, 73-82.

Dwivedi, R.D., Singh, P.K., Singh, T.N., Singh, D.P., 1998. Compressive strength and tensile strength of rocks at sub-zero temperature. Indian J. Eng. Mat. Sc. 5, 43-48.

Dwivedi, R.D., Soni, A.K., Goel, R.K., Dube, A.K., 2000. Fracture toughness of rocks under sub-zero temperature conditions. Int. J. Rock Mech. \& Mining Sciences 37, 1267-1275.

Eberhardt, E., Stead, D., Stimpson, B., 1999. Quantifying progressive pre-peak brittle fracture damage in rock during uniaxial compression. Int. J. Rock Mech. Min. Sci. 36, 361-380.

Eberhardt, E., Spillmann, T., Maurer, H., Willenberg, H., Loew, S., Stead, D., 2004. The Randa Rockslide Laboratory: Establishing brittle and ductile instability mechanisms using numerical modelling and microseismicity, 9th Int. Symposium of Landslides A.A. Balkema, Rio de Janeiro, pp. 481-487.

Einstein, H.H., Veneziano, D., Baecher, G.B., O'Reilly, K.J., 1983. The effect of discontinuity Persistence an Rock Slope Stability. Int. J. Rock Mech. Min. Sci. \& Geomech. Abstr. 20, 227-236.

Erismann, T.H., Abele, G., 2001. Dynamics of Rockslides and Rockfalls. Springer, Berlind a.o.

Fischer, L., Huggel, C., 2008. Methodical Design for Stability Assessments of Permafrost-Affected High-Mountain Rock Walls. In: Kane, D.L., Hinkel, K.M. (Eds.), 9th Int. Conf. on Permafrost. INE-UAF, Fairbanks, Alaska, US, pp. 439444.

Fischer, L., Huggel, C., Lemy, F., 2007. Investigation and modeling of periglacial rock fall events in the European Alps. Geophysical Research Abstracts 9, 08160.

Fischer, L., Kääb, A., Huggel, C., Noetzli, J., 2006. Geology, glacier retreat and permafrost degradation as controlling factors of slope instabilities in a highmountain rock wall: the Monte Rosa east face. Nat. Hazards Earth Syst. Sci. 6, 761-772.

Fischer, L., Amann, F., Moore, J.R., Huggel, C., 2010. Assessment of periglacial slope stability for the 1988 Tschierva rock avalanche (Piz Morteratsch, Switzerland). Engineering Geology 116, 32-43.

Geertsema, M., Clague, J.J., Schwab, J.W., Evans, S.G., 2006. An overview of recent large catastrophic landslides in northern British Columbia, Canada. Engineering Geology 83, 120-143. 
Glamheden, R., 2001. Thermo-Mechanical Behaviour of Refrigerated Caverns in Hard Rock. Chalmers University of Technology, Göteborg.

Goodman, R.E., 1970. The deformability of joints. In: Materials, A.S.T.a. (Ed.), Determination of the insitu Modulus of deformation of rock. Spec. Tech. Publications, pp. 174-196.

Gruber, S., Haeberli, W., 2007. Permafrost in steep bedrock slopes and its temperature-related destabilization following climate change. Journal of Geophysical Research - Earth Surface 112, F02S13.

Gruber, S., Hoelzle, M., Haeberli, W., 2004. Permafrost thaw and destabilization of Alpine rock walls in the hot summer of 2003. Geophys. Res. Lett. 31, L15054.

Günzel, F., 2008. Shear Strength of Ice-Filled Rock Joints. In: Kane, D.L., Hinkel, K.M. (Eds.), 9th Int. Conf. on Permafrost. INE-UAF, Fairbanks, Alaska, US, pp. 581-586.

Günzel, F., 2012. Shear strength of rock joints filled with frozen sand. In: Hinkel, K.M. (Ed.), 10th International Conference on Permafrost, Salekhard, Russia, pp. 143-148.

Haeberli, W., 1992. Construction, environmental problems and natural hazards in periglacial mountain belts. Permafrost and Periglac. Process. 3, 111-124.

Haeberli, W., 2005. Investigating glacier-permafrost relationships in high-mountain area: historical background, selected examples and research needs. In: Harris, C., Murton, J.B. (Eds.), Cryospheric Systems: Glaciers and Permafrost. Geological Society Special Publication, London, pp. 29-37.

Haeberli, W., Wegmann, M., Vonder Mühll, D., 1997. Slope stability problems related to glacier shrinkage and permafrost degradation in the Alps. Eclogae Geologicae Helvetiae 90, 407-414.

Haeberli, W., Huggel, C., Kääb, A., Polkvoj, A., Zotikov, I., Osokin, N., 2003. Permafrost conditions in the starting zone of the Kolka-Karmadon rock/ice slide of 20 September 2002 in North Ossetia (Russian Caucasus), 8th Int. Conf. on Permafrost, Zurich, Switzerland, pp. 49-50.

Haeberli, W., Huggel, C., Kääb, A., Zgraggen-Oswald, S., Polkvoj, A., Galushkin, I., Zotikov, I., Osokin, N., 2004. The Kolka-Karmadon rock/ice slide of 20 September 2002: an extraordinary event of historical dimensions in North Ossetia, Russian Caucasus. Journal of Glaciology 50, 533-546.

Hall, K., Thorn, C.E., Matsuoka, N., Prick, A., 2002. Weathering in cold regions: some thoughts and perspectives. Progress in Physical Geography 26, 577603.

Hallet, B., 2006. Geology - Why do freezing rocks break? Science 314, 1092-1093.

Hallet, B., Walder, J.S., Stubbs, C.W., 1991. Weathering by segregation ice growth in microcracks at sustained sub-zero temperatures: verification from an experimental study using acoustic emissions. Permafrost and Periglacial Processes 2, 283-300.

Hasler, A., Talzi, I., Beutel, J., Tschudin, C., Gruber, S., 2008. Wireless Sensor Networks in Permafrost Research: Concept, Requirements, Implementation, and Challenges. In: Kane, D.L., Hinkel, K.M. (Eds.), 9th Int. Conf. on Permafrost. INE-UAF, Fairbanks, U.S., pp. 669-674.

Hoek, E., Brown, E.T., 1980. Empricial strength criterion for rock masses. J. Geotech. Engng Div. 106, 1013-1035.

Holm, K., Bovis, M., Jakob, J., 2004. The landslide response of alpine basins to postLittle Ice Age glaical thinning and retreat. Geomorphology 57, 201-216.

Huggel, C., 2009. Recent extreme slope failures in glacial environments: effects of thermal perturbation. Quaternary Science Reviews 28, 1119-1130. 
Huggel, C., Caplan-Auerbach, J., Waythomas, C.F., Wessels, R.L., 2007. Monitoring and modelling ice-rock avalanches from ice-capped volcanoes: a case study of frequent large avalanches on Iliamna Volcano, Alaska. Journal of Volcanology and Geothermal Research 168, 114-136.

Huggel, C., Gruber, S., Caplan-Auerbach, J., Wessels, R.L., Molnia, B.F., 2008. The 2005 Mt. Steller, Alaska, Rock-Ice Avalanche: A Large Slope Failure in Cold Permafrost. In: Kane, D.L., Hinkel, K.M. (Eds.), 9th Int. Conf. on Permafrost. INE-UAF, Fairbanks, Alaska, US, pp. 747-752.

Inada, Y., Yokota, K., 1984. Some Studies of Low-Temperature Rock Strength. Int. J. Rock Mech. Min. Sci. 21, 145-153.

Indraratna, B., Welideniya, H.S., Brown, E.T., 2005. A shear strength model for idealised infilled joints under constant normal stiffness. Geotechnique 55, 215226.

Irwin, G.R., 1958. Fracture. In: Flügge, S. (Ed.), Handbuch der Physik 6. Springer, Berlin, pp. 551-590.

Kemeny, J., 2003. The time-dependent reduction of sliding cohesion due to rock bridges along discontinuities: A fracture mechanics approach. Rock. Mech. Rock Eng. 36, 27-38.

Konrad, J.M., Morgenstern, N.R., 1982. Prediction of frost heave in the laboratory during transient freezing. Canadian Geotechnical Journal 31, 250-259.

Körner, H., Ulrich, R., 1965. Geologische und felsmechanische Untersuchungen für die Gipfelstation der Seilbahn Eibsee - Zugspitze. Geologica Bavarica 55, 404-421.

Korup, O., Clague, J.J., 2009. Natural hazards, extreme events, and moutain topography. Quaternary Science Reviews 28, 977-990.

Korup, O., Densmore, A.L., Schlunegger, F., 2010. The role of landslides in mountain range evolution. Geomorphology 120, 77-90.

Krautblatter, M., Dikau, R., 2007. Towards a uniform concept for the comparison and extrapolation of rockwall retreat and rockfall supply. Geografiska Annaler 89 A, 21-40.

Krautblatter, M., Hauck, C., 2007. Electrical resitivity tomography monitoring of permafrost in solid rock walls. Journal of Geophysical Research - Earth Surface 112, F02S20.

Krautblatter, M., Verleysdonk, S., Flores-Orozco, A., Kemna, A., 2010. Temperaturecalibrated imaging of seasonal changes in permafrost rock walls by quantitative electrical resistivity tomography (Zugspitze, German/Austrian Alps). Journal of Geophysical Research-Earth Surface 115, F02003.

Krautblatter, M., Huggel, C., Deline, P., Hasler, A., 2012. Research perspectives for instable high-alpine bedrock permafrost: measurement, modelling and process understanding. Permafrost and Periglacial Processes 23, 80-88.

Krus, M., 1995. Feuchtetransport und Speicherkoeffizienten poröser mineralischer Baustoffe - theoretische Grundlagen und neue MeßtechnikenPh.D., University of Stuttgart, Stuttgart.

Li, N., Zhang, P., Chen, Y., Swoboda, G., 2003. Fatigue properties of cracked, saturated and frozen sandstone samples under cyclic loading. Int. J. Rock Mech. \& Mining Sciences 40, 145-150.

Lipovsky, P., Evans, S., Clague, J., Hopkinson, C., Couture, R., Bobrowsky, P., Ekstrom, G., Demuth, M., Delaney, K., Roberts, N., Clarke, G., Schaeffer, A., 2008. The July 2007 rock and ice avalanches at Mount Steele, St. Elias Mountains, Yukon, Canada. Landslides 5, 445-455. 
Matsuoka, N., 1990. Mechanisms of Rock Breakdown by Frost Action - an Experimental Approach. Cold Reg Sci Technol 17, 253-270.

Matsuoka, N., 2001. Direct Observation of Frost Wedging in Alpine Bedrock. Earth Surf. Process. Landforms 26, 601-614.

Matsuoka, N., Murton, J., 2008. Frost weathering: Recent advances and future directions. Permafrost and Periglacial Processes 19, 195-210.

McColl, S.T., 2012. Paraglacial rock-slope stability. Geomorphology, 1-16.

Mellor, M., 1973. Mechanical Properties of Rocks at Low Temperatures, 2nd Int. Conference on Permafrost, Yakutsk, Russia, pp. 334-344.

Messerli, B., 2006. From nature-dominated to human-dominated global environmental change in the mountains of the world. In: Price, M.F. (Ed.), Global Chnage in Mountain Regions. Sapiens Publishing, Duncow, pp. 3-5.

Miller, H., 1961. Der Bau des westlichen Wettersteingebirges. Z. dt. geol. Ges. 113, 409-425.

Murton, J.B., Peterson, R., Ozouf, J.C., 2006. Bedrock fracture by ice segregation in cold regions. Science 314, 1127-1129.

Murton, J.B., Coutard, J.-P., Lautridou, J.P., Ozouf, J.-C., Robinson, D.A., Williams, R.B.G., Guillemet, G., Simmons, P., 2000. Experimental design for a pilot study on bedrock weathering near the permafrost table. Earth Surf. Process. Landforms 25, 1281-1294.

Nixon, J.F., 1982. Frost heave predictions using the segregation potential concept Canadian Geotechnical Journal 19, 526-529.

Noetzli, J., Gruber, S., 2009. Transient thermal effects in Alpine permafrost. The Cryosphere 3, 85-99.

Noetzli, J., Hoelzle, M., Haeberli, W., 2003. Mountain permafrost and recent Alpine rock-fall events: a GIS-based approach to determine critical factors. In: Phillips, M., Springman, S., Arenson, L. (Eds.), 8th International Conference on Permafrost. Swets \& Zeitlinger, Zurich.

Paterson, W.S.B., 2001. The Physics of Glaciers. Butterworth \& Heinemann, Oxford.

Patton, F.D., 1966. Multiple modes of shear failure in rock, 1st Congress Int. Society for Rock Mech. Lab. of Civil Engineering, Lisbon, Portugal, pp. 509-513.

Pogrebiskiy, M.I., Chernyshev, S.N., 1977. Determination of the Permeability of the Frozen Fissured Rock Massif in the Vicinity of the Kolyma Hydroelectric Power Station. Cold Regions Research and Engineering Laboratory - Draft Translation 634, 1-13.

Prager, C., Zangerl, C., Patzelt, G., Brandner, R., 2008. Age distribution of fossil landslides in the Tyrol (Austria) and its surrounding areas. Natural Hazards and Earth System Sciences 8, 377-407.

Prick, A., 1997. Critical degree of saturation as a threshold moisture level in frost weathering of limestones. Permafrost and Periglacial Processes 8, 91-99.

Rabatel, A., Deline, P., Jaillet, S., Ravanel, L., 2008. Rock falls in high-alpine rock walls quantified by terrestrial lidar measurements: A case study in the Mont Blanc area. Geophys. Res. Lett. 35, L10502.

Ravanel, L., Deline, P., 2008. La face ouest des Drus (massif du Mont-Blanc). Évolution de l'instabilité d'une paroi rocheuse dans la haute montagne alpine depuis la fin du petit age glaciaire. Geomorphologie 4, 261-272.

Renshaw, C.E., Schulson, E.M., 2001. Universal behaviour in compressive failure of brittle materials. Nature 412, 897-900.

Sanderson, T., 1988. Ice mechanics and risks to offshore structures. Springer, Amsterdam. 
Sass, O., 2005. Rock moisture measurements: Techniques, results, and implications for weathering. Earth Surf. Process. Landforms 30, 359-374.

Sass, O., Krautblatter, M., Morche, D., 2007. Rapid lake infill following major rockfall (bergsturz) events revealed by ground-penetrating radar (GPR) measurements, Reintal, German Alps. Holocene 17, 965-976.

Schulson, E.M., Duval, P., 2009. Creep and fracture of ice. University Press, Cambridge.

Slaymaker, O., 2009. Proglaical, periglacial or paraglacial? In: Knight, J., Harrison, S. (Eds.), Periglacial and Paraglacial Processes and Environments. Geological Society Special Publications, London, pp. 268-288.

Sosio, R., Crosta, G.B., Hungr, O., 2008. Complete dynamic modeling calibration for the Thurwieser rock avalanche (Italian Central Alps). Engineering Geology 100, 11-26.

Tang, G.Z., Wang, X.H., 2006. Modeling the thaw boundary in broken rock zones in permafrost in the presence of surface water flows. Tunnelling and Underground Space Technology 21, 684-689.

Terzaghi, K., 1962. Stability of steep slopes in hard unweathered rock. Geotechnique 12, 251-270.

Tharp, T.M., 1987. Conditions for crack propagation by frost wedging. Geol. Soc. Am. Bull. 99, 94-102.

Ulrich, R., King, L., 1993. Influence of mountain permafrost on construction in the Zugspitze mountains, Bavarian Alps, Germany, 6th Int. Conf. on Permafrost, Bejing, pp. 625-630.

Walder, J., Hallet, B., 1985. A Theoretical-Model of the Fracture of Rock During Freezing. Geol. Soc. Am. Bull. 96, 336-346.

Weertman, J., 1973. Creep of ice. In: Whalley, E., Jones, S.J., Gold, L.W. (Eds.), Physics and Chemistry of Ice. Royal Soc. of Canada, Ottawa, pp. 320-337.

Wegmann, M., Gudmundsson, G.H., Haeberli, W., 1998. Permafrost changes in rock walls and the retreat of Alpine glaciers: a thermal modelling approach. Permafrost and Periglac. Process. 9, 23-33.

Whalley, W.B., 1982. Crack propagation and associated weathering in igneous rocks. Z. Geomorph. 26, 33-54.

Whalley, W.B., 1984. Rockfalls. In: Brunsden, D., Prior, D.B. (Eds.), Slope Instability. Wiley \& Sons, Chichester, pp. 217-256.

Whalley, W.B., Bruce, B.R., Rainey, M.M., 2004. Weathering, blockfields, and fracture systems and the implications of long-term landscape formation: some evidence from Lingen and Oksforddjokelen areas in North Norway. Polar Geography 28, 93-119. 


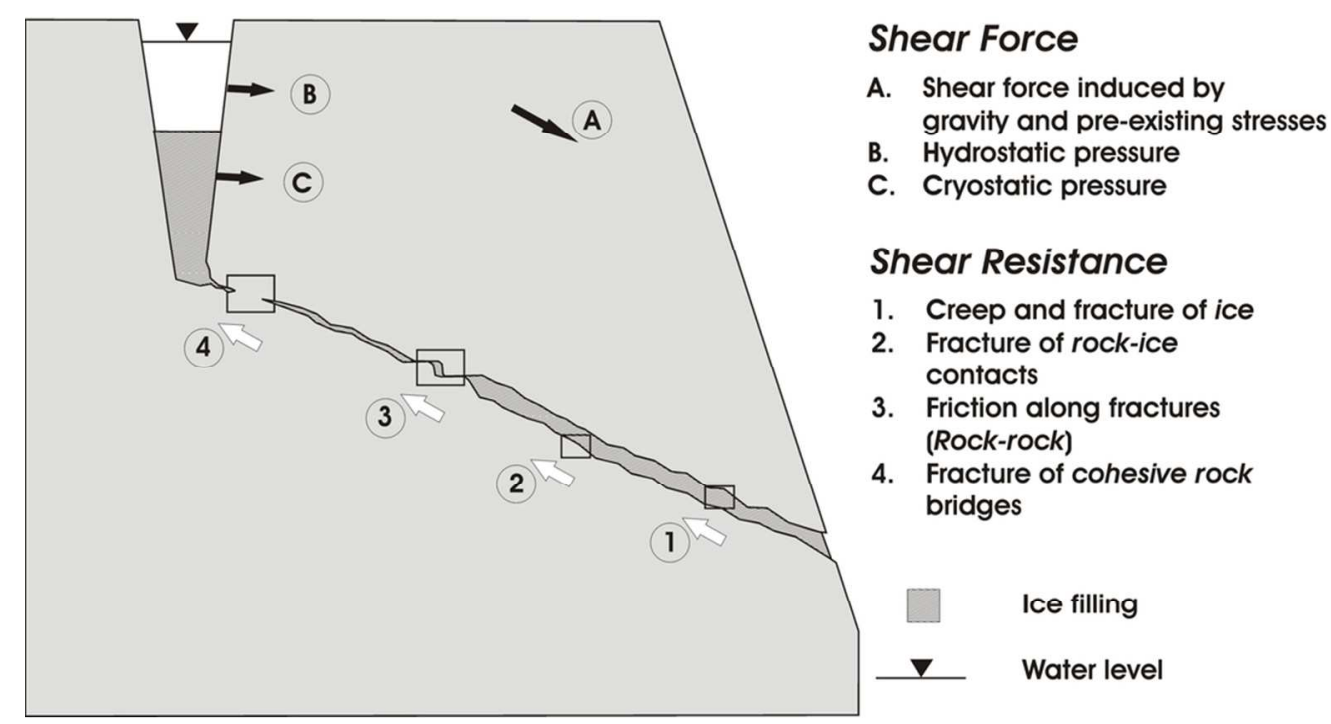

A schematic representation of the rock-ice mechanical model $91 \times 49 \mathrm{~mm}(300 \times 300$ DPI $)$ 

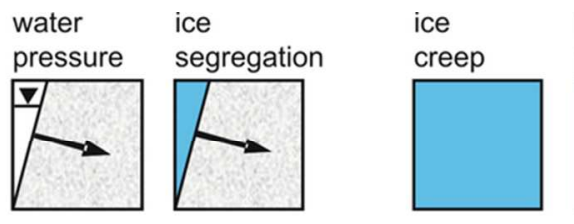

ice
fracture

rock-ice rock-rock rock

pressure

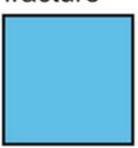
separation

friction

fracturing
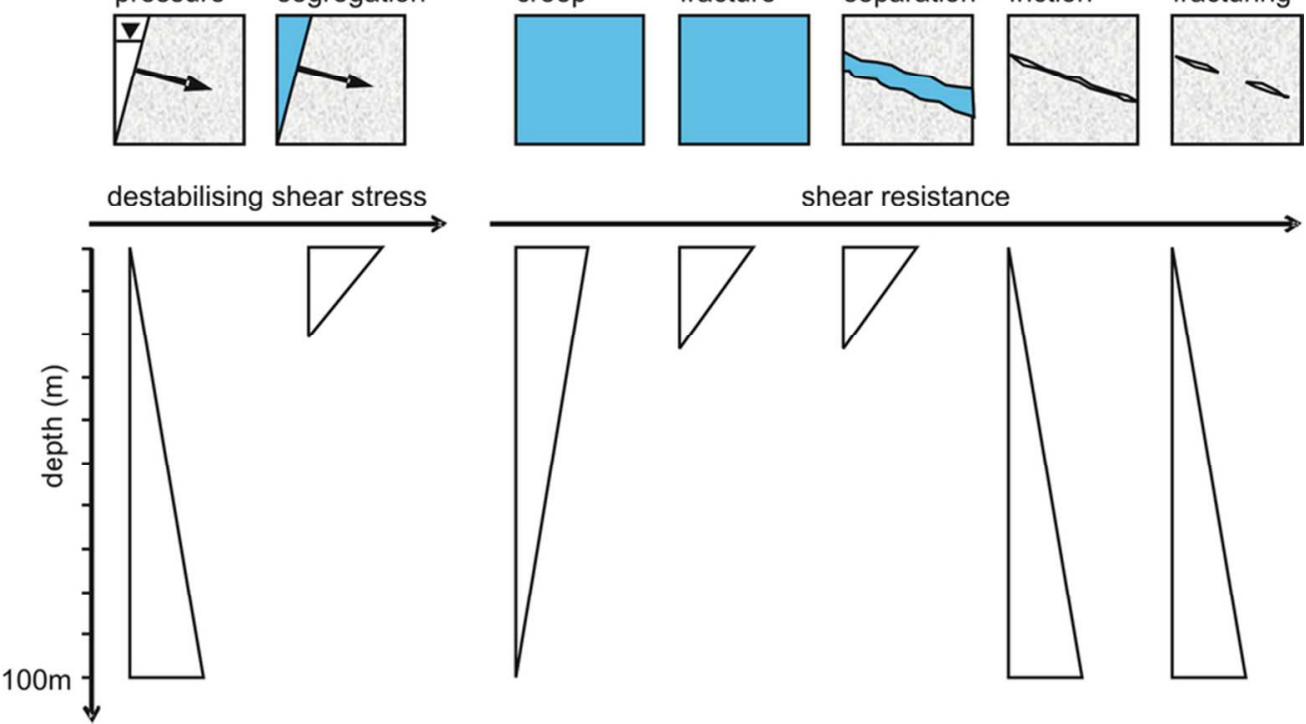

The efficiency of shear force and shear resistance with depth of the shear plane. $75 \times 45 \mathrm{~mm}(300 \times 300$ DPI $)$ 


1
2
3
4
5
6
7
8
9
10
11
12
13
14
15
16
17
18
19
20
21
22
23
24
25
26
27
28
29
30
31
32
33
34
35
36
37
38
39
40
41
42
43
44
45
46
47
48
49
50
51
52
53
54
55
56
57
58
60

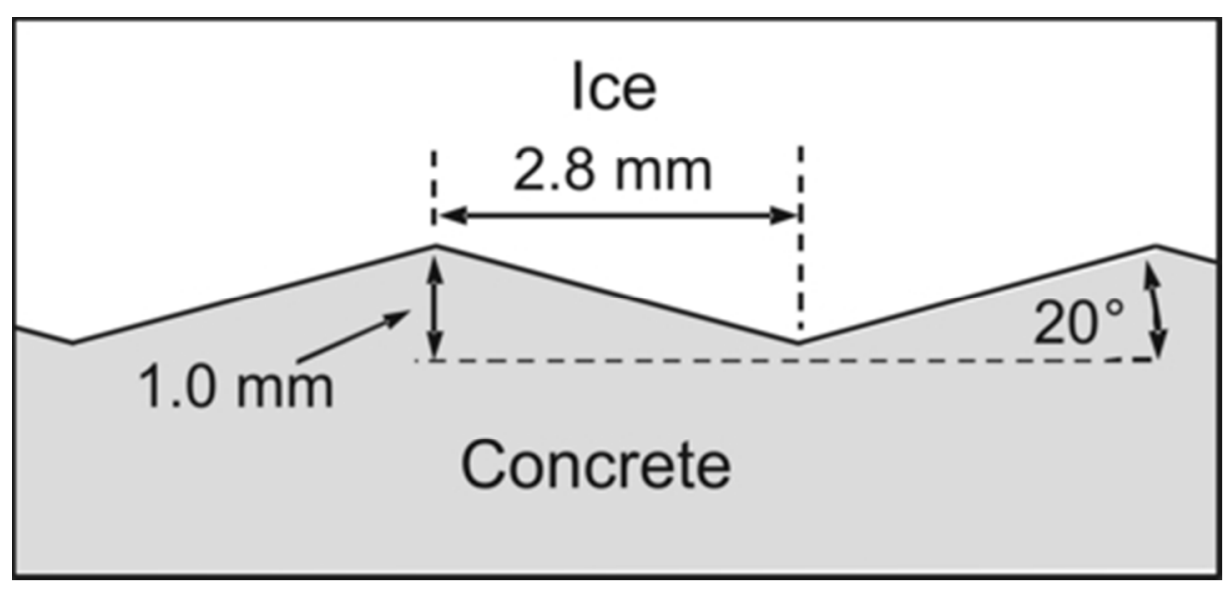

Dimensions of the saw-tooth surface $39 \times 18 \mathrm{~mm}(300 \times 300 \mathrm{DPI})$ 
a)

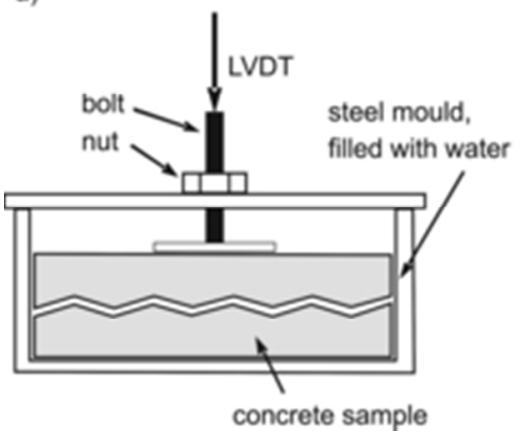

b)

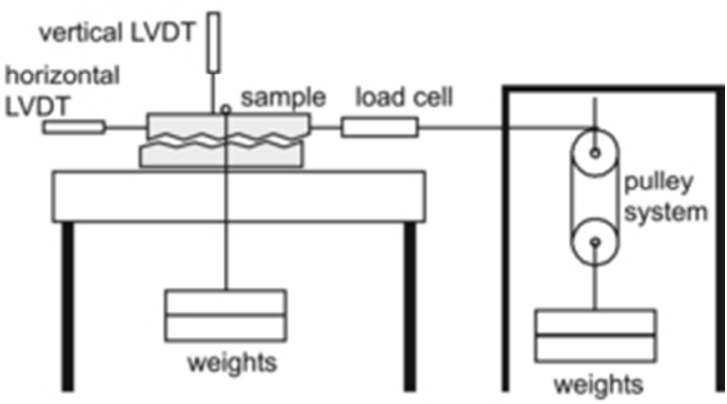

a) Preparation of sandwich sample; b) Schematic overview over experimental set-up of the constant stress tests

$43 \times 15 \mathrm{~mm}(300 \times 300$ DPI $)$

21

22

23

24

25

26

27

28

29

30

31

32

33

34

35

36

37

38

39

40

41

42

43

44

45

46

47

48

49

50

51

52

53

54

55

56

57

58

59

60

http://mc.manuscriptcentral.com/esp 
Results of a constant stress experiment (concrete-ice sample, normal stress $=207 \mathrm{kPa}$ ) plotted against time.

$72 \times 44 \mathrm{~mm}(300 \times 300$ DPI) 


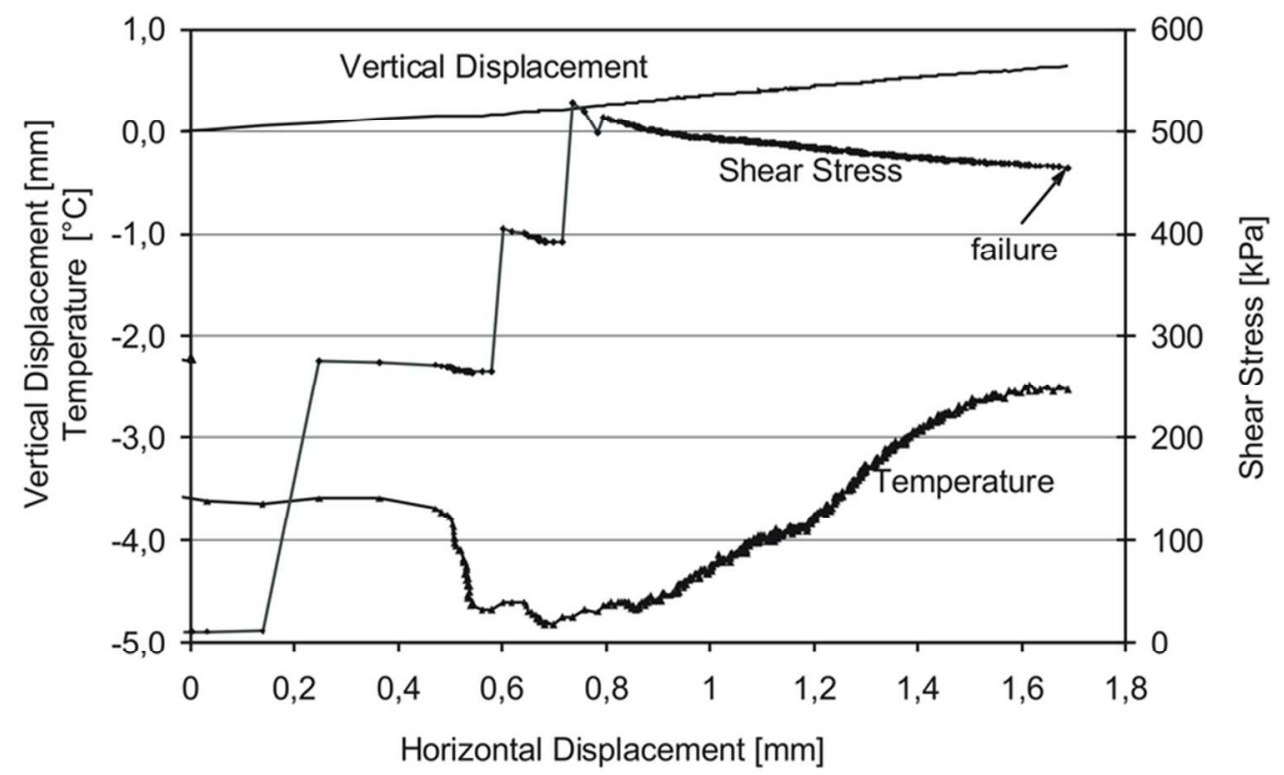

Results of a constant stress experiment (concrete-ice sample, normal stress $=207 \mathrm{kPa}$ ) plotted against horizontal displacement.

$72 \times 44 \mathrm{~mm}(300 \times 300 \mathrm{DPI})$ 


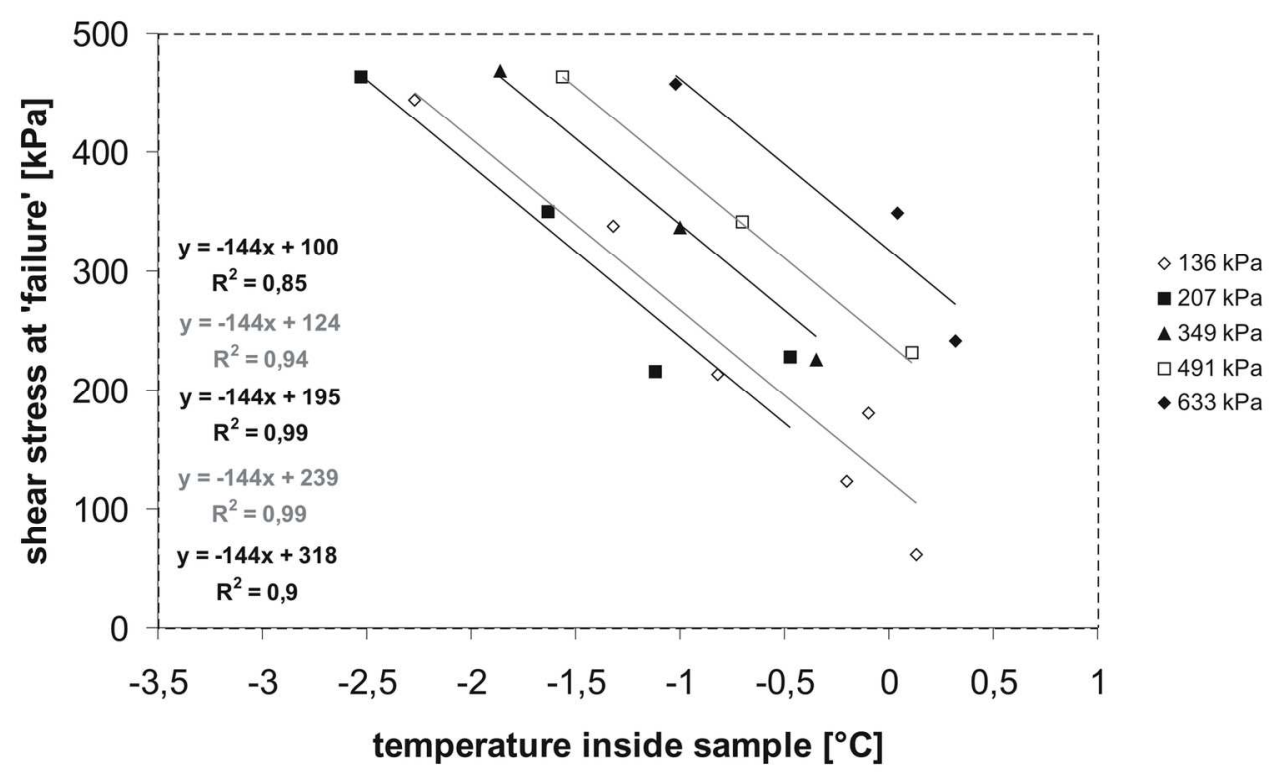

Shear stress at failure plotted against failure temperature for constant-stress tests with concrete-ice samples.

$75 \times 47 \mathrm{~mm}(600 \times 600 \mathrm{DPI})$ 


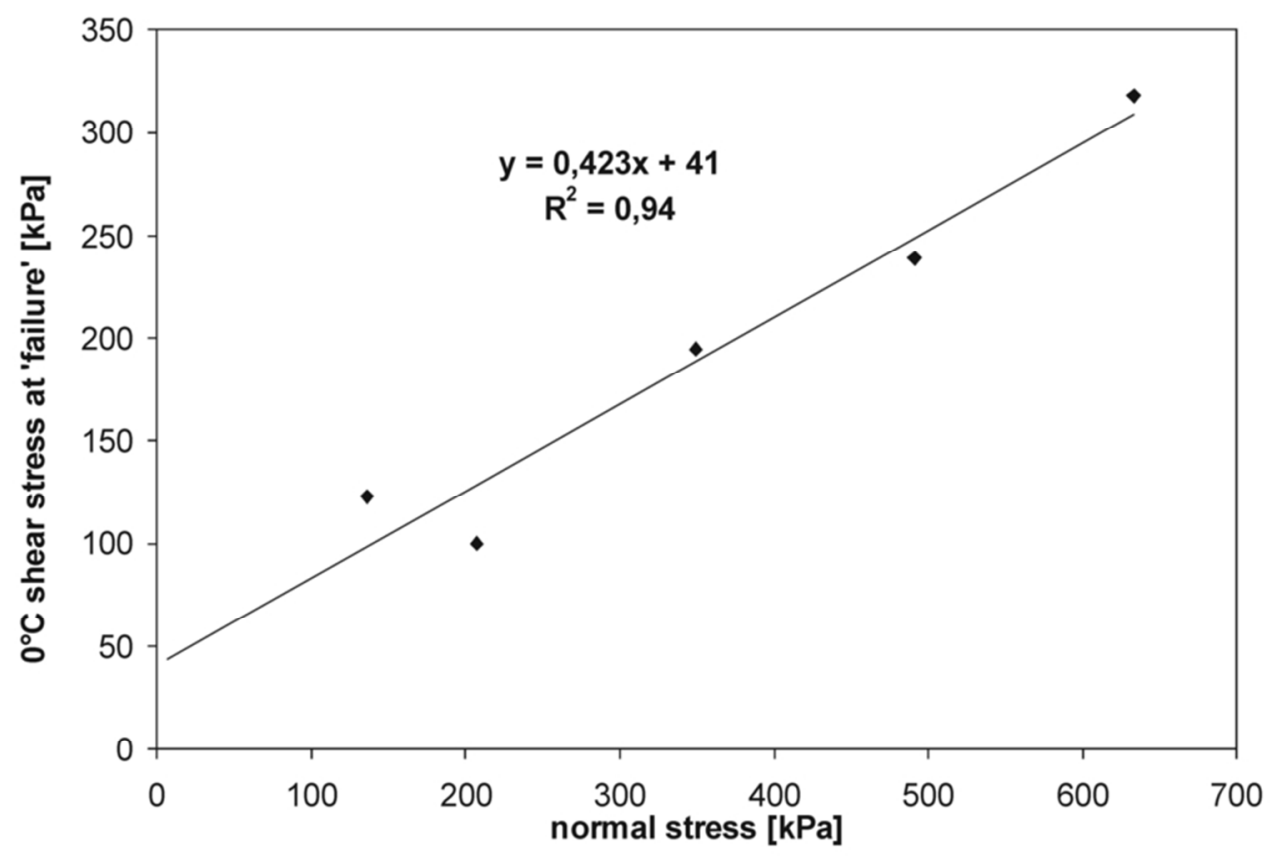

Linear relationship of shear stress at failure vs. normal stress for constant stress tests for $0^{\circ} \mathrm{C}$. $77 \times 51 \mathrm{~mm}(300 \times 300 \mathrm{DPI})$ 
1

2

3

4

5

6

7

8

9

10

11

12

13

14

15

16

17

18

19

20

21

22

23

24

25

26

27

28

29

30

31

32

33

34

35

36

37

38

39

40

41

42

43

44

45

46

47

48

49

50

51

52

53

54

55

56

57

58

59

60
A) D1

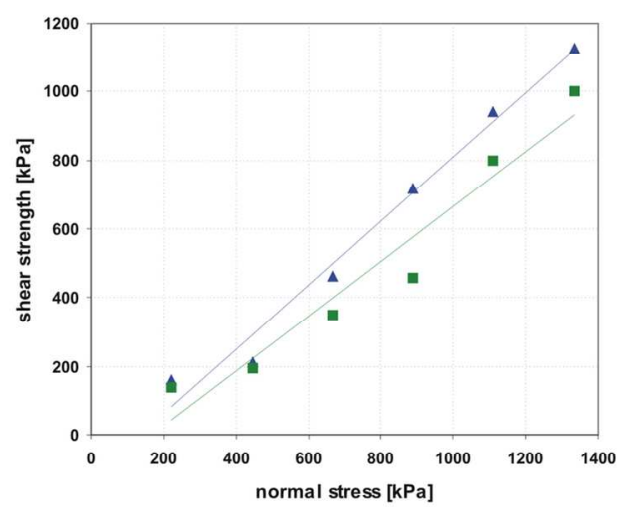

L1

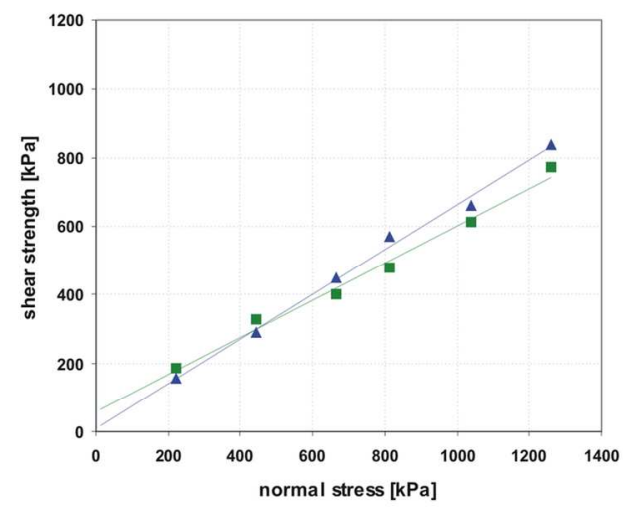

$\boldsymbol{\Delta}=$ frozen tests

- unfrozen tests

C) L2

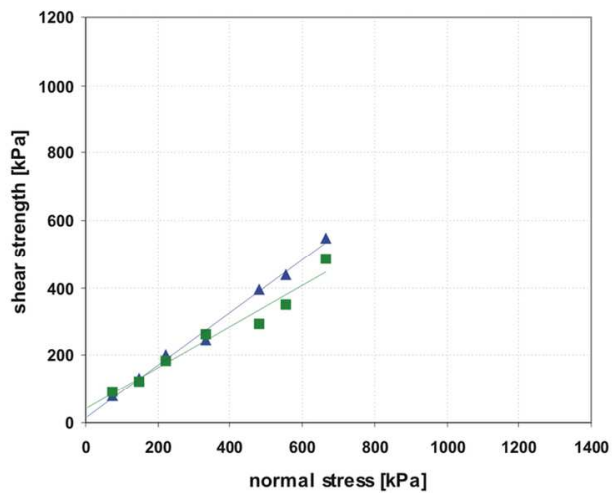

Peak shear strength - normal stress relationships for direct shear tests on the dolomite sample (D1) and limestone samples (L1, L2) performed with constant velocities. $136 \times 125 \mathrm{~mm}(300 \times 300 \mathrm{DPI})$ 